University for Business and Technology in Kosovo

UBT Knowledge Center

Oct 28th, 9:00 AM - Oct 30th, 5:00 PM

\title{
Improving Business Networking through the Effective Utilisation of Information Systems
}

Ylber Limani

University for Business and Technology, ylber.limani@ubt-uni.net

Follow this and additional works at: https://knowledgecenter.ubt-uni.net/conference

Part of the Databases and Information Systems Commons, and the Information Security Commons

\section{Recommended Citation}

Limani, Ylber, "Improving Business Networking through the Effective Utilisation of Information Systems" (2016). UBT International Conference. 3.

https://knowledgecenter.ubt-uni.net/conference/2016/all-events/3

This Event is brought to you for free and open access by the Publication and Journals at UBT Knowledge Center. It has been accepted for inclusion in UBT International Conference by an authorized administrator of UBT Knowledge Center. For more information, please contact knowledge.center@ubt-uni.net. 
Book of Proceedings

International Conference on Information Systems and Security

\title{
Improving Business Networking through the Effective Utilisation of Information Systems
}

\author{
Ylber Limani \\ UBT - Higher Education Institution, Lagjja Kalabria, 10000 p.n., \\ Prishtine, Kosovo \\ ylber.limani@ubt-uni.net
}

\begin{abstract}
This Research addresses topics concerned with the enterprise models and information systems. The research is divided into two parts, in the first part is conducted the examination of business information systems in general, while in the second part the main factors of business networking are investigated.

The existing operational business practices and Information Technology infrastructure are not sufficiently used of efficiently sustain the effective business networking. A methodical analysis of the operational systems is performed in order to cover the main elements of the Infoamtion Systems and their utilisation for business needs. The implementation of a most important information business systems requires technology, knowledge and proper environment. The research shows how different companies cope with the utilisation of Business Information Systems In all these case studies, the implementation of information systems requires learning how technology works, how to transfer the knowledge from partnerships needed to support the research, the participation in the data base of supply network and to support the Supply Chain Management (SCM) and Customer Relationship Management (CRM) models. Although, there were problems during the implementation of IS Models, these have being resolved using various approaches.

The discussion in this research further is oriented towards the planning of resources in enterprises, including key components in this context. An effective incorporation of IS models includes all processes such as: Operations, Accounting, Finance, Marketing, Human Resources, SCM, and CRM. The results of this research explain the function of IS models in the framework of integration of SCM and CRM by emphasising the improvement of business network. This research utilises descriptive analysis and comparative technique of observed issues from the studied topic. The results are focused on clarification of the relationship having limited practical approach.
\end{abstract}

Keywords: Business networking, Information systems, SCM, CRM, integration.

\section{Introduction}

Enterprise Resource Planning (ERP) is a broadly used industry tool aimed at facilitating the flow of information in order to make business decisions based on processed data. The decisions driven by data can be backed up and confirmed.

It can be assumed that approaches based on processed data are gaining attractiveness within the enterprise as the quantity of accessible data increases exponentially with market densities. 
Improving Business Networking through the Effective Utilisation of Information Systems

In this regard an abundant ERP software sets are constructed which are intended to identify, to collect and organize data from various structures of an organisation. Those date sets are designed to provide management with insight into business metrics which can be used to evaluate factors that are crucial to the success of an organization, e.g. costumer relationship metrics and supplier relationship metrics.

The main objective of this research is to conduct a descriptive analysis of main issues concerned with ERP. This objective is supposed to be achieved through analytical approach of most important factors for the implementation of ERP system in the organisations.

Questions addressed in this research:

1. How ERP has been implemented?

2. What are the obstacles for ERP system implementation?

3. How can ERP systems be integrated with CRM and SCM?

The ERP Implementation cases are used to identify the factors affecting the failure of ERP systems, and the key success factors in the cases of successful ERP system implementations.

The results are used to construct the conclusions and the recommendations for organisations which are potentially aiming at ERP implementation.

\subsection{The methodology}

The main goal of ERP implantation is to answer the question how to extract value from data?

The main assumption of this research

ERP Implementation is about business solution design which could be implemented through integration of change management, business strategy and business performance.

For successful implementation of any ERP a health organisation structure supported by strong IT team and equipment is required.

Analysis and successful utilisation of data sets can find new correlations to business processes, business trends and can lead to innovations.

\section{ERP Implementation factors}

An ERP system is defined as a representation of a fully integrated business management system covering functional parts of an enterprise like Operations, Logistics, Production, Finance, Accounting and Human Resources. The ERP system supports the business process by integrating the information systems and by enabling smooth and continuous flow of information across functional levels and departmental partitions of organisation (Leon, 2008).

ERP help to automate business processes and functions by enabling the organisation to operate as a single entity by having clear view on resources (Leon, 2008).

Organizations are under continuous strain from customers, shareholders, and suppliers to take actions towards more effective design, planning and continues improvement of products and services. The organisations are becoming more dynamic and more competitive. Competing in a dynamic business environment and meeting new challenges requires speed and flexibility (Addo-Tenkorang and Helo, 2011).

Change management is becoming a complex issue considering that organisations need to make fast decisions in order to follow the trends. There are various changes in business process and they can stream beginning from shift in customer demands and supplier conditions, getting to the functioning 
Book of Proceedings

International Conference on Information Systems and Security

and modifications of business model or business process, business network configuration, integration, and ending by implementation of standards and regulations. Organizations need to optimise the operations and processes in order to improve their productivity effectively and efficiently. In this regard, the utilisation of extended information systems is critical to their existence.

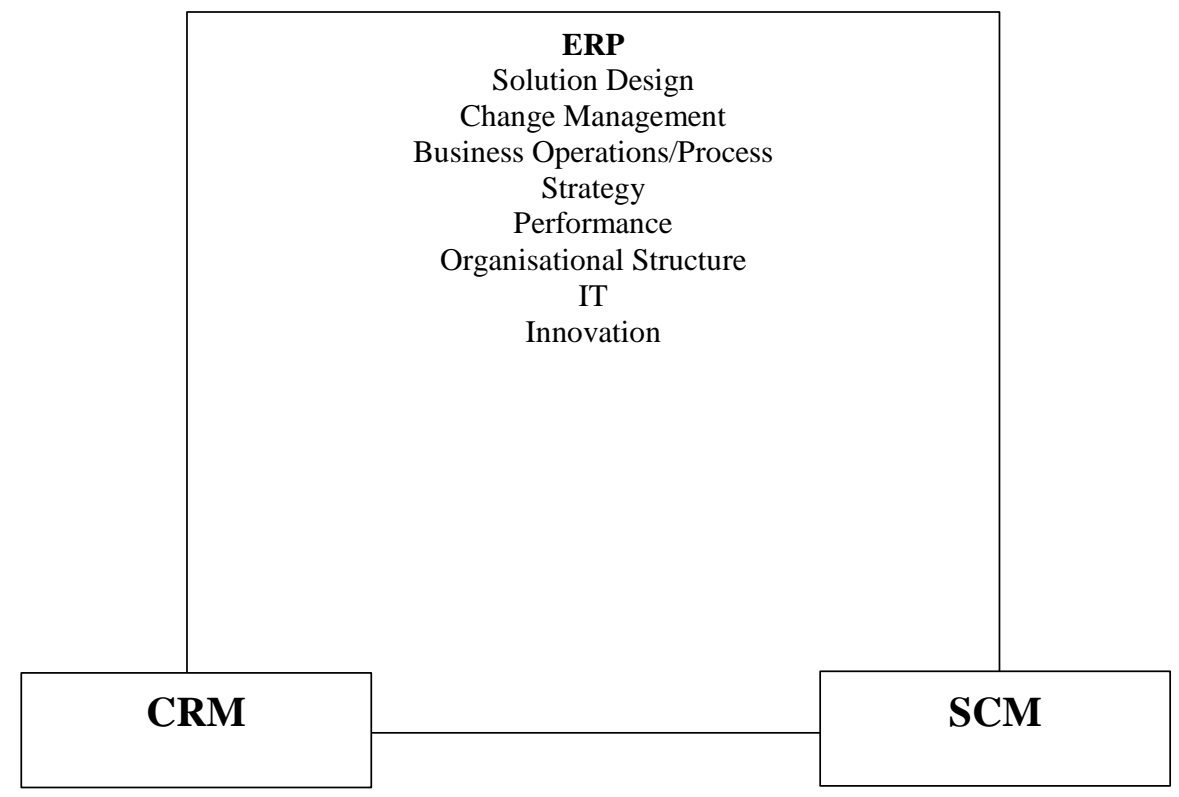

Figure 1: Factors determining the successful integration of ERP Systems

7 ERP Factors:

1. Business Operations/Process

2. Strategy

3. Performance

4. Business Network System

5. Organisational Structure

6. IT

7. Innovation 
Improving Business Networking through the Effective Utilisation of Information Systems

Table 1: ERP Implementation failure reports

\begin{tabular}{|l|l|}
\hline ERP failures reports & Reasons \\
\hline Panorama Consulting, 2014 & $\begin{array}{l}\text { Change management } \\
\text { Twenty percent (20\%) of respondents quoted change } \\
\text { management issues like training, resistance to change, process } \\
\text { redesign as an overwhelming reason for implementation failure. }\end{array}$ \\
\hline Gartner, 2011 & $\begin{array}{l}\text { Under-investment in Organisational Change Management } \\
\text { Gartner survey found that companies under-invest in } \\
\text { organizational change management. Companies allocate, on } \\
\text { average, only 5\% of the overall system implementation budget to } \\
\text { the change management effort }\end{array}$ \\
\hline $\begin{array}{l}\text { ERP lmplementation Failure at } \\
\text { Hershey Foods Corporation } \\
\text { (ICFAI Center for } \\
\text { management } \\
\text { (2008). Research, }\end{array}$ & $\begin{array}{l}\text { Big Bang approach to ERP implementation instead of Phased } \\
\text { approach } \\
\text { In this approach, the software modules was to be implemented at } \\
\text { one single phase. Manugistics }{ }^{2} \text { and Siebel }{ }^{3} \text { where software } \\
\text { vendors. }\end{array}$ \\
\hline
\end{tabular}

Problems raised at Hershey: order fulfilment pertaining, processing and shipping disorders, incomplete deliveries, delayed shipments, missing deadlines, disordered supplier and retailer balance, loss of precious shelf pace, disorder of costumer relationship, late sending the consignements, the inventory levels increase (ICFAI Center for management Research, 2008).

Analytics identified that the problem had happened due to a number of informal constructions within the company. SAP R/3 ERP implementation requirements included the need to add all the data relating to the location of the inventory and its specifics. Because of ERP implementation overrun Hershey decided to place products wherever the space was available in order fulfil the increased demand. Those locations where not identified by the new SAP and they were not taken into account. The created circumstance caused inventory increase in one side, and delay in shipments at another way (ICFAI Center for management Research, 2008). The main reason for the failure was the deficiency in communication and coordination between the technical-functional workers implementing the system and the people involved in operations functions, who did not update the SAP with data concerned with the informal storage of goods.

During the ERP implementation crises numerous orders remained unfulfilled by Hershey. Hershey's failure to implement the ERP software on time costed the company US\$ 150 million in sales. There was a profit drop by $19 \%$ for the third quarter 1999, and by $12 \%$ decline in sales. In its 1999 annual report, Hershey stated, "The reduction in shipments resulted primarily from difficulties in order fulfilment (customer service, warehousing, and shipping) encountered since the start-up of a new integrated information system and new business processes during the third quarter of 1999". Hershey confirmed that the problem was with getting the customer orders into the system and transmitting them to the warehouses (Hershey Food Corporation, 1999).

\footnotetext{
${ }^{1}$ Cadbury has implemented new ERP oriented on ERP which was very successful

${ }^{2}$ Manugistics would provide software for transport management, production, forecasting and scheduling

${ }^{3}$ The software from Siebel was to support Hershey in managing customer relations and in tracking the effectiveness of the company's marketing through a pricing promotions module
} 
Book of Proceedings

International Conference on Information Systems and Security

It was estimated that during the third and fourth quarter of 1999, Hershey lost about $0.50 \%$ market share (ICFAI Center for management Research, 2008).

Hershey recovered from losses in 2002.

Table 2: Financial performance of Hershey Food Coorporation in 1999, 2000, and in 2001, 2002, and 2014.

\begin{tabular}{|l|l|l|l|l|l|}
\multicolumn{7}{|c|}{ Adapted from: Hershey Food Corporation (2001, 2002, 2015) } \\
\hline Metric & 1999 & 2000 & 2001 & 2002 & 2014 \\
\hline $\begin{array}{l}\text { Net Income } \\
\text { million \$ }\end{array}$ & $\$ 460,310$ & $\$ 334,543$ & $\$ 207,156$ & $\$ 403,578$ & $\$ 846,912$ \\
\hline
\end{tabular}

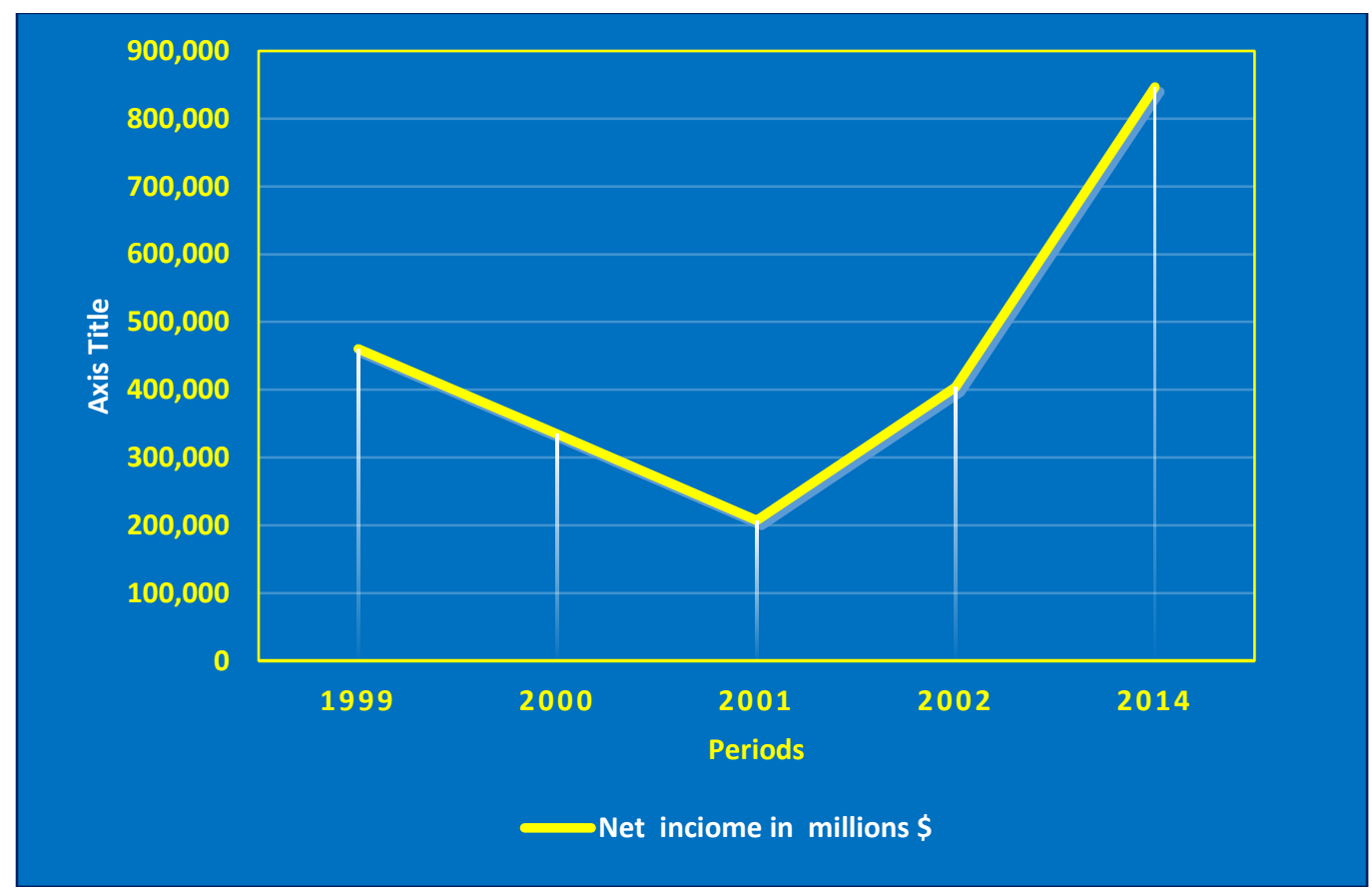

Figure 2: The impact of ERP implementation failure on financial performance Adapted from: Hershey Food Corporation (2001, 2002, 2015) 
Improving Business Networking through the Effective Utilisation of Information Systems

\section{ERP Integration within SCM and CRM}

\section{ERP and CRM Integration}

Businesses need ERP and CRM applications when they start to have troubles on keeping the customers satisfaction with their services, when they do not have exact figures of inventory on the warehouse etc. The integration of ERP and CRM to the companies, can provide real time mobile access to data. ERP and CRM jointly may create an interconnection to the e-commerce features by linking the ERP application with customer support to CRM. From the side of the company, the integration of ERP and CRM may provide the synchronization of the product catalogues from the ERP to CRM, which can shorten the time that clients can have access to the new products.

With other words, the integration of ERP and CRM will provide a helicopter view of organizational profitability. Sales and Marketing departments will no longer be waiting for the orders and requests by customers but they will be working hard to predict the costumer's requirements. As a result of the integration, you will have the opportunity of clarifying the factors that may effect on your supply chain, and as well manage the inventory and lead time.

\section{ERP and CRM Integration}

Businesses need ERP and CRM applications when they start to have troubles on keeping the customers satisfaction with their services, when they do not have exact figures of inventory on the warehouse etc. The integration of ERP and CRM to the companies, can provide real time mobile access to data. ERP and CRM jointly may create an interconnection to the e-commerce features by linking the ERP application with customer support to CRM. From the side of the company, the integration of ERP and CRM may provide the synchronization of the product catalogs from the ERP to CRM, which can shorten the time that clients can have access to the new products.

With other words, the integration of ERP and CRM will provide a helicopter view of organizational profitability. Sales and Marketing departments will no longer be waiting for the orders and requests by customers but they will be working hard to predict the costumer's requirements. As a result of the integration, you will have the opportunity of clarifying the factors that may effect on your supply chain, and as well manage the inventory and lead time.

\section{References}

1. Leon A. (2008) Enterprise Resource Planning. $2^{\text {nd }}$ Edition, Tata McGraw-Hill

2. 2014 ERP Report: What is the Current State of Global ERP Implementations? [Online] http://panorama-consulting.com/resource-center/2014-erp-report/

3. Lessons from 169 SAP Implementations Using Service Providers in North America, Gartner, March 2011

4. R. Addo and Tenkorang and P. Helo (2011) Proceedings of the World Congress on Engineering and Computer Science $2011 \mathrm{Vol}$ II

5. WCECS 2011, October 19-21, 2011, San Francisco, USA Scribd. (2010). ERP Implementation at Cadbury's. [Online] http://www.scribd.com/doc/39650132/ERP-IMPLEMENTATION-AT-CADBURY-S

6. ICFAI Center for management Research (2008). ERP lmplementation Failure at Hershey Foods Corporation. Case study [online] 
Book of Proceedings

International Conference on Information Systems and Security

http://members.home.nl/c.schalkx/Cases\%20ARP/ERP\%20Implementation\%20Failure\%20Hers hey\%20Foods\%20Corporation.pdf

7. Hershey Food Corporation (1999). Management Discussion and Analysis, Annual Report [online] http://www.getfilings.com/o0000047111-00-000070.html

8. Hershey Food Corporation (2015). 2015 Proxy Statement/2014 Annual Report/Form 10-K [online] https://www.thehersheycompany.com/pdfs/PDF_Proxy\%20Statement_2014.pdf

9. Hershey Food Corporation (2001). 2001 Annual Report Management Discussion and Analysis [online] http://media.corporate-ir.net/media_files/NYS/HSY/reports/HSY_2001_AR.pdf

10. Hershey Food Corporation (2002). 2002 Annual Report Management Discussion and Analysis [online] http://media.corporate-ir.net/media_files/NYS/HSY/reports/HSY_MDA_2002.pdf 